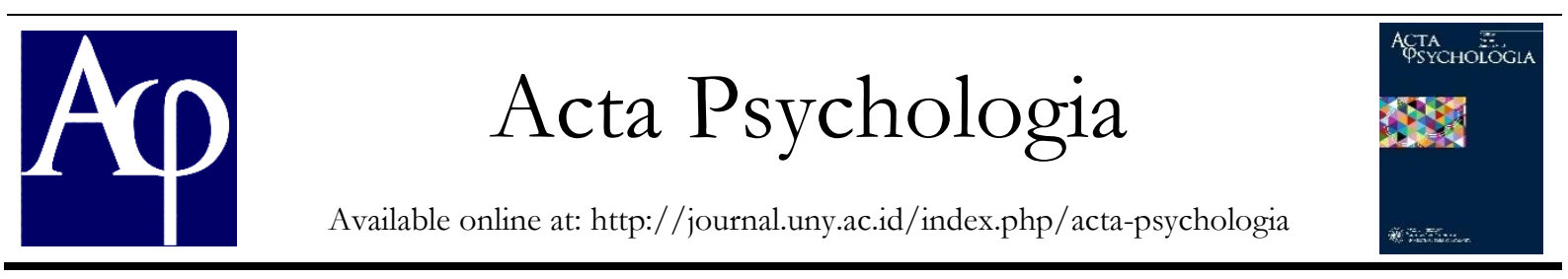

\title{
Hubungan Perilaku Prososial dengan Persepsi Penerimaan Teman Sebaya pada Remaja Awal
}

\author{
Ika Apriani Dewi Saputri, Yulia Ayriza \\ Jurusan Psikologi, Fakultas Ilmu Pendidikan, Universitas Negeri Yogyakarta; \\ Jl. Colombo No. 1 Sleman Yogyakarta, 55281 \\ ikaapriani883@gmail.com
}

\begin{abstract}
Abstrak
Penelitian ini bertujuan untuk meneliti hubungan antara perilaku prososial dengan persepsi penerimaan teman sebaya pada remaja awal di SMP N 1 Ngawen, Gunungkidul. Dalam penelitian ini pendekatan yang digunakan adalah pendekatan kuantitatif dengan jenis penelitian korelasional. Populasi dalam penelitian ini berjumlah 665 siswa, dengan sampel berjumlah 96 siswa. Instrumen pengumpulan data berupa skala perilaku prososial dan skala persepsi penerimaan teman sebaya. Skala perilaku prososial terdiri dari 24 item dengan reliabilitas sebesar 0, 933 dan skala persepsi penerimaan teman sebaya terdiri dari 20 item dengan reliabilitas sebesar 0, 927. Berdasarkan hasil analisis data menggunakan korelasi product moment menunjukkan bahwa terdapat hubungan antara perilaku prososial dengan persepsi penerimaan teman sebaya pada remaja awal di SMP N 1 Ngawen dengan nilai korelasi sebesar 0,889 dan signifikasi $\mathrm{p}<0,05$. Dengan demikian semakin tinggi perilaku prososial maka semakin tinggi persepsi penerimaan teman sebaya, demikian pula sebaliknya.
\end{abstract}

Kata Kunci: prososial, perspesi penerimaan teman sebaya, remaja, korelasi

\begin{abstract}
The objective of this study is to identify the relationship between prosocial behaviour and the perception of peer acceptance in the early stage of the adolescent at SMP N 1 Ngawen, Gunungkidul. In this study, the researcher used a quantitative approach with a correlational method. The population in this study were 96 students as a sample out of 665 students in total. The data collection instruments were the scale of prosocial behaviour and peer acceptance's perception. The prosocial behaviour scale consists of 24 items with the reliability of 0,933 and the perception of peer acceptance scale consists of 20 items with the reliability of 0,927 . Based on the result of data analysis that used a product-moment correlation, it shows that there was a relationship between prosocial behaviour and the perception of peer acceptance in an early adolescent at SMP N 1 Ngawen with a correlational value of 0,889 and signification of $\mathrm{p}>0,05$ which means the higher the prosocial behaviour, the higher the peer acceptance's perception and vice versa
\end{abstract}

Keywords: prosocial, perception of peer acceptance, adolescent, correlation

\section{Pendahuluan}

Masa remaja merupakan masa terjadinya perubahan dinamis di diri individu dalam bentuk fisik, cara berpikir, pola hubungan sosial dimana waktu yang sudah tidak lagi banyak dihabiskan dengan orangtua (Brooks, 2011). Remaja lebih banyak terlibat dalam hal-hal yang yang bertujuan menyenangkan diri sendiri dengan dengan teman-temannya. Oleh karena itu, penerimaan teman sebaya menjadi salah satu hal penting bagi remaja.

Penerimaan teman sebaya melibatkan pemahaman kognitif terhadap orang lain dan diri sendiri serta perilaku pertemanan yang sesuai (Brooks, 2011). Penerimaan teman sebaya menjadi salah satu kebutuhan remaja, selain kebutuhan berhubungan dengan orangtua (Mappiare, 1982). Lebih lanjut dinyatakan oleh 
Mappiare (1982) bahwa arti penting penerimaan teman sebaya bagi seorang remaja adalah adanya rasa berharga dan berarti serta dibutuhkan bagi atau oleh kelompoknya. Namun, tidak semua remaja awal mampu membentuk hubungan yang baik dengan teman sebaya baik di sekolah maupun di luar sekolah. Salah satu contohnya yaitu kasus yang menimpa salah satu siswa Sekolah Menengah Pertama (SMP) berinisial ES di daerah Klaten, Jawa Tengah yang kesulitan dalam menjalin pertemanan dengan teman sebayanya (Tyas, 2015). ES mengaku bahwa dirinya adalah murid pendiam, sangat pemalu, pencemas, suka menyendiri, dan menarik diri dari teman-temannya, teman-temannya pun juga malas dengan ES karena sifatnya yang kurang menyenangkan seperti mudah tersinggung, sensitif, mukanya yang menunjukkan ekspresi tidak menyenangkan ketika dimintai pertolongan, dan ES yang perfeksionis.

Dari kasus di atas dapat dilihat bahwa tindakan yang memberikan manfaat kepada orang lain dibutuhkan dalam penerimaan teman sebaya yaitu perilaku prososial. Namun sayangnya tidak semua remaja awal mampu membentuk hubungan yang baik dengan teman sebaya. Kecenderungan remaja untuk melakukan perilaku prososial mulai menurun atau bahkan jarang ditemui. Perilaku prososial merupakan suatu tindakan individu yang dapat memberikan manfaat kepada orang lain (Baron \& Branscombe, 2012). Perilaku prososial remaja lebih diarahkan pada teman sebaya yang difokuskan ke arah untuk membangun hubungan. Perilaku prososial yang lebih tinggi dapat memberikan perlindungan pada anak, karena kemungkinan kecil untuk di tolak dalam hubungan pertemanan mereka (Greener, 2000).

Penelitian yang dilakukan Saleem, Barlett, Anderson, dan Hawkins (2016) menemukan bahwa remaja yang menunjukkan perilaku prososial yang rendah cenderung menunjukkan tanggung jawab sosial yang rendah, memiliki kecenderungan untuk menyakiti orang lain, dan menampilkan perilaku agresi yang tinggi. Hal tersebut menunjukkan bahwa remaja yang tidak memiliki perilaku prososial dan menampilkan perilaku maladaptif cenderung tidak diinginkan atau bahkan ditolak dalam kelompok pertemanan sebayanya. Penelitian yang dilakukan Handayani (2016) tentang pengaruh perilaku prososial dan kepercayaan diri terhadap penerimaan teman sebaya menunjukkan hasil bahwa perilaku prososial berpengaruh secara signifikan terhadap penerimaan teman sebaya, hal ini menunjukkan bahwa peningkatan dan penurunan penerimaan teman sebaya dipengaruhi oleh perilaku prososial.

Dalam hubungan pertemanan sebaya pada remaja, remaja yang diterima baik oleh teman-temannya dalam kelompok teman sebaya adalah individu yang dapat memberikan manfaat bagi orang lain. Seperti halnya perilaku prososial, remaja yang memiliki perilaku prososial yang baik akan cenderung disukai dan diterima dalam kelompok teman sebaya. Perilaku prososial merupakan tindakan secara sukarela untuk membantu atau memberikan manfaat kepada setiap individu atau kelompok lain (Einsberg \& Mussen, 1989). Remaja yang memiliki perilaku prososial cenderung memilih teman yang memiliki perilaku prososial juga.

Seorang remaja memandang bahwa teman sebayanya dapat menerima mereka dalam kelompok teman sebaya, maka mereka akan tahu bagaimana harus berperilaku dalam kelompok teman sebaya tersebut. Jadi, dapat dikatakan bahwa persepsi penerimaan teman sebaya adalah proses memaknai ekspresi wajah, perlakuan, kesediaan untuk membantu sebagai indikasi diterima dalam kelompok teman sebaya tersebut. 
Berdasarkan uraian di atas, dapat disimpulkan bahwa penerimaan teman sebaya adalah hal penting bagi remaja. Salah satu faktor yang memengaruhi penerimaan sebaya yaitu perilaku prososial. Perilaku prososial dibutuhkan dalam pertemanan remaja sebab remaja membutuhkan teman yang bisa mendukung dan memberikan manfaat yang ada bagi dirinya. Oleh karena itu pada studi ini peneliti bertujuan untuk mengkaji hubungan antara perilaku prososial dengan persepsi penerimaan teman sebaya pada remaja awal.

\section{Metode Penelitian}

\section{Jenis penelitian}

Penelitian ini menggunakan pendekatan kuantitatif. Menurut Azwar (2018) pendekatan kuantitatif adalah metode yang menekankan analisisnya pada data-data kuantitatif (angka) yang dikumpulkan melalui prosedur pengukuran dan diolah dengan metode analisis statistika. Penelitian ini menggunakan metode penelitian korelasional, yaitu penelitian yang bertujuan untuk mengetahui kekuatan dan arah hubungan yang ada di antara variabel-variabel yang di ukur (Azwar, 2018).

\section{Waktu dan tempat penelitian}

Penelitian ini dilaksanakan di SMP Negeri 1 Ngawen yang beralamat di Gantiwarno, Kampung, Ngawen, Gunungkidul, Daerah Istimewa Yogyakarta. Pengambilan data dilaksanakan pada tanggal 12 Februari 2020, hingga 27 Juli 2020 hingga 31 Agustus 2020.

\section{Populasi dan sampel penelitian}

Populasi penelitian didefinisikan sebagai kelompok subjek yang hendak dikenai generalisasi hasil penelitian. Sebagai suatu populasi, kelompok subjek tersebut harus memiliki beberapa ciri atau karakteristik bersama yang membedakan dari kelompok subjek lainnya (Azwar, 2018). Populasi dalam penelitian ini adalah siswa SMP Negeri 1 Ngawen, Gunungkidul berjumlah 665 siswa dengan rincian 221 siswa kelas VII, 223 siswa kelas VIII, dan 221 siswa kelas IX. Setiap kelas terdiri dari 7 kelompok yaitu kelompok A sampai G.

Sampel adalah sebagian dari subjek populasi, dengan kata lain sampel adalah bagian dari populasi. Setiap bagian dari populai merupakan sampel, terlepas dari apakah bagian itu mewakili karakteristik populasi secara lengkap atau tidak (Azwar, 2018). Sampel dalam penelitian ini ditentukan dengan rumus Slovin (Sugiyono, 2011) yaitu $n=\frac{N}{1+N(e)^{2}}$ dengan penetapan nilai krisis (batas ketelitian) sebesar 10\%. Minimal sampel dalam penelitian ini yaitu sebanyak 87 siswa.

Teknik sampling yang dilakukan yaitu dengan teknik stratified random sampling. Subjek penelitian akhir yang terlibat dalam penelitian ini yaitu siswa kelas VII B, VIII B, IX A SMP Negeri 1 Ngawen yang masing-masing kelas terdiri dari 32 siswa. Dengan demikian total subjek penelitian sebanyak 96 siswa.

\section{Teknik pengumpulan data dan instrumen}

Pengumpulan data dilakukan dengan skala psikologi berbentuk likert-scale dengan 5 alternatif pilihan jawaban pada setiap instrumen. Skala psikologi terdiri dari beberapa item yang secara tidak langsung mengungkapkan atribut yang akan diukur. Perilaku diukur melalui indikator perilaku dari atribut yang bersangkutan (Azwar, 2016). Instrumen yang digunakan dalam penelitian ini adalah Skala Perilaku Prososial dan Skala Persepsi Penerimaan Teman Sebaya. Skala penelitian terdiri dari lima pilihan respon yaitu (1) sangat tidak sesuai, (2) tidak sesuai, (3) netral, (4) sesuai, dan (5) sangat sesuai. Skala Perilaku Prososial berjumlah 20 item dengan nilai reliabilitas 0,933, sedangkan Skala Persepsi 
Penerimaan Teman Sebaya berjumlah 24 item dengan reliabilitas 0,927 .

\section{Teknik. Analisis data}

Teknik analisis data dilakukan dengan analisis deskriptif dan inferensial dengan korelasi product moment dari Pearson.

\section{Analisis deskriptif}

Analisis deskriptif yaitu analisis yang bertujuan untuk mendeskripsikan data dari variabel yang diperoleh (Azwar, 2018). Data dikumpulkan melalui penyebaran kuesioner yang dibentuk dalam skala pengukuran. Dalam penelitian ini skala pengukuran yang digunakan adalah skala Likert dengan lima pilihan respon yaitu dari 1 (sangat tidak sesuai), 2 (tidak sesuai), 3 (antara sesuai atau tidak sesuai), 4 (sesuai), dan 5 (sangat sesuai). Setelah didapat skor total, skor kemudian dikategorisasikan menggunakan rumus di Tabel 1.

Tabel 1. Norma Kategorisasi

\begin{tabular}{ll}
\hline \multicolumn{1}{c}{ Kategorisasi } & \multicolumn{1}{c}{ Rumus } \\
\hline Sangat Tinggi & $\mathrm{X}>\mu+1,5 \sigma$ \\
Tinggi & $\mu+0,5 \sigma<\mathrm{X} \leq \mu+1,5 \sigma$ \\
Sedang & $\mu-0,5 \sigma<\mathrm{X} \leq \mu+0,5 \sigma$ \\
Rendah & $\mu-1,5 \sigma<\mathrm{X} \leq \mu-0,5 \sigma$ \\
Sangat Rendah & $\mathrm{X} \leq \mu-1,5 \sigma$ \\
\hline
\end{tabular}

Keterangan :

$\mu \quad$ : mean teoritik

$\mathrm{X}$ : skor

$\sigma \quad$ : satuan standard deviation

\section{Uji Korelasi}

Uji hipotesis dalam penelitian ini dilakukan dengan korelasi product moment dari Pearson dengan bantuan SPSS For Windows. Koefisien korelasi $\mathrm{r}_{\mathrm{xy}}$ menunjukkan kekuatan hubungan yang dinyatakan oleh angka yang berkisar dari 0 sampai dengan 1 , dan arah hubungan yang dinyatakan oleh tanda positif atau tanda negatif. Koefisien korelasi bertanda positif menunjukkan terdapat hubungan linier positif antara $\mathrm{X}$ dan $Y$, yang dinterpretasikan jika variabel
$\mathrm{X}$ meningkat maka Variabel $\mathrm{Y}$ juga meningkat begitu juga sebaliknya. Koefisien korelasi negatif menunjukkan terdapat hubungan linier negatif atau berlawanan arah antara $\mathrm{X}$ dan $\mathrm{Y}$, yang diinterpretasikan jika variabel $\mathrm{X}$ semakin tinggi maka variabel $\mathrm{Y}$ semakin rendah begitu juga sebaliknya (Azwar, 2018).

Koefisien korelasi yang didapat kemudian diinterpretasi berdasarkan panduan dari Sugiyono (2012) pada tabel Tabel 2.

Tabel 2. Interpretasi koefisien korelasi

\begin{tabular}{ll}
\hline \multicolumn{1}{c}{ Koefisien korelasi } & \multicolumn{1}{c}{ Interpretasi } \\
\hline $0.00-0.19$ & Sangat lemah \\
$0.20-0.59$ & Lemah \\
$0.60-0.79$ & Kuat \\
$0.80-1.00$ & Sangat kuat \\
\hline
\end{tabular}

\section{Hasil Penelitian dan Pembahasan}

\section{Hasil Uji Deskriptif}

Data perilaku prososial memiliki mean= $60, \mathrm{SD}=13.3$, skor minimal $=20$, dan skor maksimal $=100$. Berdasarkan uji deskriptif, tidak ada siswa yang memiliki skor prososial $\leq 40$ atau kategori sangat rendah; sebanyak 1 siswa (1\%) memiliki skor antara 40 hingga $\leq 53$ atau kategori rendah; sebanyak 7 siswa $(7 \%)$ memiliki skor antara 53 hingga $\leq 67$ atau kategori sedang; sebanyak 26 siswa $(27 \%)$ memiliki skor antara 67 hingga $\leq 80$ atau kategori tinggi; dan sebanyak 62 siswa (65\%) memiliki skor di atas 80 atau kategori sangat tinggi. Jadi sebagian besar siswa SMP N 1 Ngawen memiliki perilaku sosial sangat tinggi yaitu 62 siswa $(65 \%)$ dari total 96 siswa.

Untuk data persepsi penerimaan teman sebaya memiliki mean $=72, \mathrm{SD}=$ sebesar 16. Skor minimal 24, dan skor maksimal 120. Berdasarkan uji deskriptif, tidak ada siswa yang memiliki skor di bawah 64; sebanyak 7 (7\%) siswa memiliki skor antara 64 hingga $\leq 80$ atau masuk kategori sedang; sebanyak 33 siswa (35\%) 
memiliki skor antara 80 hingga $\leq 96$ atau kategori tinggi; dan sebanyak 56 siswa (58\%) memiliki skor di atas 96 atau kategori sangat tinggi. Jadi sebagian besar siswa SMP N 1 Ngawen memiliki tingkat penerimaan teman sebaya sangat tinggi yaitu 56 siswa (58\%) dari 96 siswa.

\section{Hasil Uji Korelasi}

Uji Hipotesis dilakukan untuk mengetahui hubungan antara perilaku prososial dengan persepsi penerimaan teman sebaya. Uji hipotesis dilakukan dengan uji korelasi Product Moment dari Pearson dengan bantuan SPSS for Windows. Hasil pengujian dapat dilihat pada Tabel 3.

Tabel 3. Hasil uji korelasi

\begin{tabular}{lll}
\hline & & $\begin{array}{l}\text { Persepsi } \\
\text { penerimaan }\end{array}$ \\
\hline Prososial & Pearson Correlation & $.889^{* *}$ \\
& Sig. (2-tailed) & .000 \\
& $\mathrm{~N}$ & 96 \\
\hline
\end{tabular}

Berdasarkan tabel 3. Besar korelasi Product Moment yaitu 0.889 dengan nilai signifikansi sebesar 0.000 . Hal ini menunjukkan bahwa variabel perilaku prososial memiliki hubungan yang positif dengan persepsi penerimaan teman sebaya pada remaja awal di SMP N 1 Ngawen. Dengan demikian semakin tinggi perilaku prososial maka semakin tinggi pula persepsi penerimaan teman sebaya, begitu pula sebaliknya.

\section{Pembahasan}

Dari hasil analisis deskriptif terkait perilaku prososial diketahui bahwa sebagian besar subjek memiliki perilaku prososial pada kategori sangat tinggi yaitu sebanyak 62 siswa (65\%). Dapat dikatakan siswa SMPN 1 Ngawen mampu mengekspresikan perilaku prososial terhadap teman atau orang yang berada di lingkungan sekitarnya. Hal ini sesuai dengan pendapat Baron dan Byrne (2005) yaitu perilaku prososial merupakan segala tindakan apapun yang menguntungkan orang lain tanpa harus memberikan imbalan kepada orang yang melakukan tindakan tersebut.

Adapun hasil analisis deskriptif pada variabel persepsi penerimaan teman sebaya didapatkan bahwa sebagian besar subjek yaitu sebanyak 56 subjek (58\%) memiliki persepsi penerimaan dalam sangat tinggi. Dari hasil tersebut dapat dikatakan bahwa siswa SMPN 1 Ngawen mampu menerima teman sebaya yang sesuai dengan usia dan kesukaannya baik di dalam lingkungan sekolah atau pun di luar lingkungan sekolah. Hasil tersebut sesuai dengan pendapat Berk (2011) bahwa penerimaan teman sebaya merupakan sejauh mana seorang anak dipandang atau diterima oleh sekelompok teman, seperti teman sekelas, sebagai teman yang layak. Hal ini mengacu pada kesukaan dimana seorang anak akan diterima dalam kelompok teman sebaya tersebut.

Terbuktinya hipotesis dari penelitian ini disebabkan karena perilaku prososial merupakan salah satu faktor yang menyebabkan seorang remaja diterima oleh teman sebayanya. Hal ini sesuai dengan teori yang diungkapkan dari Parker \& Asher (1993) yang menyatakan ada lima aspek dalam penerimaan teman sebaya, yaitu kepedulian, kebersamaan, bantuan dan bimbingan, kedekatan yang intim, dan resolusi konflik dengan teman sebaya. Remaja yang diterima baik oleh temantemannya dalam kelompok teman sebaya adalah anak dengan perilaku yang baik. Salah satu perilaku yang baik itu adalah perilaku prososial. Remaja yang memiliki perilaku prososial yang baik akan cenderung disukai dan diterima dalam kelompok teman sebaya. Perilaku prososial pada remaja lebih dibutuhkan untuk membangun hubungan. Semakin tinggi perilaku prososial remaja tersebut, maka semakin tinggi pula penerimaan teman sebaya. 
Remaja yang jarang atau tidak mampu memunculkan perilaku prososial cenderung kurang disenangi atau bahkan tidak disenangi dalam lingkungan sebayanya. Ketidakmauan remaja untuk berperilaku prososial cenderung dianggap bahwa remaja tersebut tidak mau terlibat jauh dengan lingkungan sekitarnya. Perilaku prososial juga memiliki dampak dalam perkembangan remaja. Dari beberapa penelitian sebelumnya menyatakan bahwa penerimaan yang positif dari teman sebaya dapat memperkirakan kompetensi sosial pada remaja di masa yang akan datang. Seperti hasil penelitian dari Zimmer-Gembeck, Geiger, dan Crick (2015) yang menyatakan bahwa perilaku prososial secara tidak langsung akan mempengaruhi perkembangan masa remaja ke masa yang akan datang.

Hartup (dalam Berk, 2012) juga berpendapat bahwa anak akan cenderung memilih teman yang memiliki kesamaan dengan diri mereka, seperti usia, jenis kelamin, ras, atnisitas, status ekonomi, kepribadian, popularitas, dan penilaian orang lain. Anak dengan perilaku prososial yang baik akan cenderung memilih teman yang memiliki perilaku prososial yang baik pula. Salah satu penyebab anak diterima oleh teman sebayanya karena memiliki perilaku prososial. Hal tersebut sesuai dengan hasil penelitian dari Handayani (2016) bahwa perilaku prososial mempengaruhi penerimaan teman sebaya. Semakin baik perilaku prososial anak, maka penerimaan teman sebayanya juga akan semakin baik.

\section{Simpulan dan Saran}

Simpulan

Berdasarkan penelitian di atas dapat disimpulkan bahwa perilaku prososial memiliki hubungan positif yang signifikan dengan persepsi penerimaan teman sebaya pada remaja awal. Dengan demikian, semakin tinggi perilaku prososial maka semakin tinggi persepsi penerimaan teman sebaya, begitu juga sebaliknya

Saran

Berdasarkan kesimpulan yang telah disebutkan sebelumnya, peneliti akan memberikan saran kepada beberapa pihak di antaranya adalah:

1. Bagi sekolah

Dari hasil penelitian di atas, remaja awal yang mampu menunjukkan perilaku prososial mendapatkan banyak keuntungan, salah satunya mendapat kemudahan untuk diterima di lingkungan teman sebayanya. Pihak sekolah dapat mendukung dengan cara menumbuhkan iklim yang kooperatif dan membiasakan perilaku prososial pada remaja awal yang dididik atau diasuhnya

2. Bagi remaja

Remaja diharapkan mampu mengoptimalkan perilaku prososial, seperti perilaku berbagi dan menolong dengan teman sebaya agar mendapatkan penerimaan yang baik.

3. Bagi peneliti selanjutnya

Dalam penelitian ini, subjek yang dilibatkan yaitu remaja awal. Bagi peneliti selanjutnya dapat memperluas cakupan subjek yaitu pada individu dewasa awal. Selain itu, penelitian ini masih terbatas pada perilaku prososial sehingga pada penelitian selanjutnya disarankan untuk menggunakan faktorfaktor lainnya yang juga dapat mempengaruhi penerimaan teman sebaya. Terkait pengukuran penerimaan teman sebaya juga bisa dilakukan dengan sosiometri. 


\section{Daftar Pustaka}

Achmadi, A. \& Narbuko, C. (2010). Metodologi penelitian. Jakarta: Bumi Aksara.

Azwar, S. (2012a). Penyusunan skala psikologi edisi II. Yogyakarta: Pustaka Pelajar.

Azwar, S. (2012b). Reliabilitas dan validitas edisi IV. Yogyakarta: Pustaka Pelajar.

Azwar, S. (2018). Metode penelitian psikologi edisi II. Yogyakarta: Pustaka Pelajar.

Baron, R. A., Branscombe. N. R. (2012). Social psychology (13thed). USA: Pearson Education, Inc.

Baron, R.A. \& Byrne, D. (2005). Psikologi sosial edisi kesepulub Jilid 2. Jakarta: Erlangga.

Berk, Laura.E. (2012). Development through the lifespan. Yogyakarta: Pustaka Pelajar.

Brooks, J. (2011). The process of parenting edisi kedelapan. Yogyakarta: Pustaka Pelajar.

Eisenberg, N., \& Mussen, P. H. (1989). The roots of prosocial behavior in children. Cambridge: Cambridge University Press.

Fadila, D. \& Ridho, S.L.Z. (2013). Perilaku Konsumen. Palembang: Penerbit Citrabooks Indonesia.

Greener, S. H. (2000). Peer assessment of children's prosocial behaviour. Journal of Moral Education, 29(1), $37-41$.

https://doi.org/10.1080/03057240 0102925.

Nurhafiza, N. (2019). Hubungan konformitas teman sebaya dengan sikap siswa terhadap perilaku prososial. Consilium: Berkala Kajian Konseling Dan Ilmu Keagamaan, 6(1), 28. https://doi.org/10.37064/consiliu m.v6i1.4813.

Handayani, P. (2016). Pengaruh perilaku prososial dan kepercayaan diri terhadap penerimaan teman sebaya. Jurnal Pendidikan Guru Sekolah Dasar, 21(2). 042-2.052. journal.student.uny.ac.id/ojs/ojs/i ndex.php/pgsd/article/view/2605.

Izzaty, R. E. (n.d.). Penerimaan teman sebaya sebagai indikator kemampuan penyesuaian diri : arti penting pengembangan karakter sejak usia dini. Fakultas Ilmu Pendidikan, Universitas Negeri Yogyakarta. 1-11. http://staffnew.uny.ac.id/upload/ 132206556/lainlain/paper+untuk+ semnas+paud.pdf.

Kotler, P., Keller, K. L. (2013). Manajemen Pemasaran Jilid Kedua. Jakarta: Erlangga.

Mappiare, A . (1982). Psikologi remaja. Surabaya: Usaha Nasional.

Mubarok, F \& Pierewan, A. C. (2018). Pengaruh penerimaan teman sebaya terhadap well-being pada remaja. Jurnal Penelitian Humaniora, 53(9), 1689-1699. https://doi.org/10.1017/CBO978 1107415324.004

Nashori, F. (2008). Psikologi sosial islami. Jakarta: PT Refika Aditama

Papalia, D. E., Old s, S. W., \& Feldman, R. D. (2009). Human development perkembangan manusia. Jakarta: Salemba Humanika.

Parker, J. G., \& Asher, S. R. (1993). Friendship and friendship quality in middle childhood: Links with peer group acceptance and feelings of loneliness and social dissatisfaction. Developmental Psychology, 29(4), 611621. https://doi.org/10.1037/00121649.29.4.611. 
Purnamasari, I., Suharso., \& Sumawan. (2018). Kontribusi empati dan dukungan sosial teman sebaya terhadap perilaku prososial siswa di SMP. Indonesian Journal of Guidance and Counseling: Theory and Application, 7(2), 20-26. journal.unnes. ac.id/sju/index.php/jbk.

Robbins, S. P. (1999). Prinsip-prinsip Perilaku Organisasi Edisi kelima. Jakarta : Erlangga.

Saleem, M., Barlett, C. P., Anderson, C. A., \& Hawkins, I. (2017). Helping and hurting others: Person and situation effects on aggressive and prosocial behavior as assessed by the Tangram task. Aggressive Behavior, 43(2), 133-146. https://doi.org/10.1002/ab.21669.

Santrock, J. W. (2007). Remaja edisi 11 jilid 2. Jakarta: Erlangga.

Santrock, J. W. (2012). Life-span development perkembangan masa bidup edisi 13 jilid 1. Jakarta: Erlangga.

Setiawati, F. A. (2017). Statistika terapan untuk penelitian pendidikan dan sosial. Yogyakarta: Parama Publishing.

Sugiyono. (2007). Metode penelitian kuantitatif kualitatif dan R\&D. Bandung: Alfabeta.

Sugiyono. (2012). Metode penelitian kuantitatif kualitatif dan R\&D. Bandung: Alfabeta.

Tyas, E. S. (2015). Hubungan antara perilaku prososial dengan penerimaan teman sebaya remaja awal. Naskah Publikasi Skripsi: Universitas Islam Indonesia.

Zimmer-Gembeck, M. J., Geiger, T. C., \& Crick, N. R. (2005). Relational and physical aggression, prosocial behavior, and peer relations: Gender moderation and bidirectional associations. Journal of Early Adolescence (Vol. 25, Issue 4). https://doi.org/10.1177/02724316 05279841 . 